\title{
Three years survival rate of epithelial ovarian cancer patients in Dr. Kariadi Hospital, Semarang, Central Java
}

\author{
Indah Nur Damayanti', Indra Yulianti ${ }^{2}$, Etty Hary Kusumastuti ${ }^{3}$ \\ 'Midwife Education Program, Faculty of Medicine, Universitas Airlangga, Surabaya, ${ }^{2}$ Department of Obstetric \\ and Gynecology, Faculty of Medicine, Universitas Airlangga, Surabaya, ${ }^{3}$ Department of Anatomical Pathology, \\ Faculty of Medicine, Universitas Airlangga, Surabaya
}

\begin{abstract}
ABSTRAK
Tujuan: mengetahui hubungan antara faktor-faktor prognostik kanker ovarium dengan kesintasan tiga tahun pasien kanker ovarium epitelial.

Bahan dan Metode: Penelitian kohort retrospektif pada 90 pasien (selama tahun 2012) di RSUP Dr. Kariadi. Kaplan Meier, Log rank, dan Cox regresi digunakan untuk menganalisa kesintasan dan faktor prognostik yang berhubungan dengan penyakit ini.

Hasil: Kesintasan 3 tahun pasien kanker ovarium epitelial secara keseluruhan adalah sebesar 58,5\% (Kaplan Meier). Kesintasan 3 tahun pasien kanker ovarium epitelial adalah sebesar $89,3 \%$, $44,4 \%$, dan $35,1 \%$, pada pasien dengan stadium I, stadium II, dan stadium III secara berurutan, dan tidak ada pasien yang bertahan hidup hingga 3 tahun pada stadium IV. Faktor prognostik yanng berhubungan dengan kesintasan 3 tahun pasien kanker ovarium epitelial yaitu stadium, asites, residu tumor, dan jenis histopatologi $\{\mathrm{p}<0,001 ; \mathrm{p}=0,001 ; \mathrm{p}=0,004 ; \mathrm{p}=0,041$, secara berurutan (uji Log rank)\}, sedangkan usia dan ukuran tumor tidak berhubungan. Setelah dilakukan analisis multivariat (Cox regresi), hanya stadium yang berhubungan dengan kesintasan 3 tahun pasien kanker ovarium epitelial.

Simpulan: Ada hubungan antara stadium, asites, residu tumor, jenis histopatolog dengan kesintasan 3 tahun penderita kanker ovarium epitelial. Stadium merupakan faktor prognostik yang paling mempengaruhi kesintasan 3 tahun penderita kanker ovarium epitelial pada penelitian ini.
\end{abstract}

Kata kunci: kanker ovarium epitelial, faktor prognostik, kesintasan 3 tahun

\begin{abstract}
Objectives: to determine the association between prognostic factors of ovarian cancer with a 3-years survival rate of epithelial ovarian cancer patients.

Material and Method: Retrospective cohort study was conducted in 90 patients (during 2012) at Dr.Kariadi General Hospital. Kaplan meier, Log rank and Cox regression were used to analyse survival rate and prognostic factors that influence the disease.

Result: Overall 3-years survival rate of epithelial ovarian cancer patients were $58.5 \%$ (Kaplan meier). Three-years survival rates were $89.3 \%, 44,4 \%$, and $35.1 \%$ for patients in stage I, stage II, and stage III, respectively, and no patient survive up to 3 years in stage IV. Prognostic factors that associated with 3-years survival rate were stage of the disease, ascites, residual tumor, and type of histopathology $\{\mathrm{p}<0,001 ; \quad \mathrm{p}=0,001 ; \quad \mathrm{p}=0,004 ; \quad \mathrm{p}=0,041$, respectively (Log rank test) $\}$, whereas age and size of tumor were not associated. After using multivariate analysis (Cox regression) only stage of the disease was associated with 3-years survival rate of epithelial ovarian cancer patients.

Conclusion: There were an association between stage of the disease, ascites, residual tumor, type of histopathology, and 3years survival rate of epithelial ovarian cancer patients. Stage of the disease was a prognostic factor that most influence 3-years survival rate of epithelial ovarian cancer patiens in this study.
\end{abstract}

Keywords: epithelial ovarian cancer, prognostic factors,

3-years survival rate

Correspondence: Indah Nur Damayanti, Barongan 3/V, Kudus, Central Java, 59312, email : damayanti.indahnur@gmail.com

\section{INTRODUCTION}

Ovarian cancer is the leading cause of death in women due to gynecologic malignancy. ${ }^{1}$ Ovarian Cancer is called The Silent Lady Killer because it is difficult to detect at an early stage so that it becomes the highest cause of death in women. In 2012 there were 238,719 new cases of ovarian cancer in the world, and there were 151,905 women die of ovarian cancer, ${ }^{2}$ Cases of ovarian cancer in developed countries was 99,752 cases, and in developing countries was 138,967 cases. While in Indonesia alone the number of cases of ovarian cancer was 10.238 and 7,075 were dead. ${ }^{3}$

The most frequently encountered types of ovarian cancer is epithelial ovarian cancer (85\% -90\%), and become the biggest cause of death from ovarian cancers.
Response to treatment of ovarian cancer can be evaluated in conjunction with prognostic factors. Prognostic factors of ovarian cancer are histopathology of tumor, differentiation of tumor cells, ploidy, stage, volume of ascites, tumors size outside the ovaries before cytoreduction, residual tumor after cytoreduction, patient's age, tumor response that is slow to chemotherapy, and performance status ( general state). ${ }^{4}$

Favorable prognostic factor is the lower stage, welldifferentiated tumor cells, no residual tumor, good general condition, and younger age. While poor prognostic factors include the clear cell and serous type of histology, advanced stage, the presence of ascites, the presence of residual tumor and older age. ${ }^{5}$ The success rate parameter of the treatment is survival after treatment. 
This study aims to determine the relationship between prognostic factors of ovarian cancer (stage, age, ascites, tumor size, residual tumor and histopathologic type with three-year survival of patients with epithelial ovarian cancer.

\section{MATERIALS AND METHODS}

This study was an observational analytic study with retrospective cohort design using secondary data from medical records of patients. The entire epithelial ovarian cancer patients who met the inclusion and exclusion criteria were enrolled as the samples in this study (90 patients). Criteria for inclusion in this study were patients who were diagnosed with epithelial ovarian cancer in 2012, had surgery and received treatment at the Hospital Dr. Kariadi (referral hospital for oncology cases in Central Java). This study was conducted in May 2016.

The data of epithelial ovarian cancer patients who were included in this study were taken and followed for 3 years from the date of diagnosis. The data taken were the date of diagnosis, stage, age at diagnosis, presence or absence of ascites before surgery, tumor size before surgery, postoperative residual tumor, histopathological type, date of death or date missing from observation. Then the tabulation and analysis of data were done. Kaplan meier, log rank and Cox regression were used to determine the survival of patients with epithelial ovarian cancer and prognostic factors that influence it.

\section{RESULTS AND DISCUSSION}

The results of the data analysis in 90 patients with epithelial ovarian cancer, who were operated at Dr. Kariadi Hospital in 2012, resulted that there were 48 patients still alive up to 3 years of observation, 6 patients lost from observation and 36 patients died before the end of the study. Based on Table 1, most of the patients were in stage III $(43.3 \%)$. More than half of the patients $(62.2 \%)$ were aged $\leq 51$ years. Patients with ascites were more than those without ascites. The size of the tumor before surgery in most patients $(57.8 \%)$ was $>$ $500 \mathrm{~cm}^{3}$. Patients that did not have postoperative residual tumor were $88.9 \%$. The most common histopathological type was type of serous (40\%). In this study, the miscellaneous categoryof histopathology was mixed cell types. From table 2 it can be seen that the test results for the Kaplan Meier overall 3 years survival of epithelial ovarian cancer patients at the Dr. Kariadi Hospital Semarang was 58.5\%.This result is similar to a research at Dharmais Cancer Hospital Jakarta stating that the 3 -years survival of patients with epithelial ovarian cancer was $56 \%{ }^{6}$ Three years survival of epithelial ovarian cancer patients in developed countries such as UK was $55.2 \%$, and in Denmark was $50 \% .^{7.8}$ Three-year survival of patients with epithelial ovarian cancer in developing countries such as Thailand was $58.6 \%{ }^{9}$ All values were slightly lower when compared with the results of this study and the differences between3-years survival of patients with epithelial ovarian cancer in developed countries and developing countries was not too much.

Table 1. Characteristics of epithelial ovarian cancer patients

\begin{tabular}{|c|c|c|}
\hline Variables & $\mathrm{n}$ & $\%$ \\
\hline \multicolumn{3}{|l|}{ Stages } \\
\hline - stage I & 38 & 42.2 \\
\hline stage II & 9 & 10 \\
\hline - stage II & 39 & 43.3 \\
\hline - stage III & 4 & 4.4 \\
\hline - stage IV & & \\
\hline \multicolumn{3}{|l|}{ Age at diagnosis } \\
\hline - $\leq 50$ years & 56 & 62.2 \\
\hline - > 50 years & 34 & 37.8 \\
\hline \multicolumn{3}{|l|}{ Ascites before surgery } \\
\hline - no ascites & 42 & 46.7 \\
\hline - with ascites & 48 & 53.3 \\
\hline \multicolumn{3}{|c|}{ Tumor size before surgery } \\
\hline - $<10 \mathrm{~cm} 3$ & 0 & 0 \\
\hline - $10-50 \mathrm{~cm} 3$ & 2 & 2.2 \\
\hline - > $50-200 \mathrm{~cm}^{3}$ & 11 & 12.2 \\
\hline - > $200-500 \mathrm{~cm}^{3}$ & 25 & 27.8 \\
\hline - $>500 \mathrm{~cm}^{3}$ & 52 & 57.8 \\
\hline \multicolumn{3}{|c|}{ Postoperative residual tumor } \\
\hline - none & 80 & 88.9 \\
\hline - $\leq 1 \mathrm{~cm}$ & 10 & 11.1 \\
\hline - $>1 \mathrm{~cm}$ & 0 & 0 \\
\hline \multicolumn{3}{|c|}{ Histopathological types } \\
\hline - mucinous & 31 & 34.4 \\
\hline - serous & 40 & 44.4 \\
\hline - endometrioid & 5 & 5.6 \\
\hline - clear cell & 10 & 11.1 \\
\hline - miscellaneous & 4 & 4.4 \\
\hline
\end{tabular}

3-year survival in stage I was $89.3 \%, 44.4 \%$ in stage II, $35.1 \%$ in stage III, andin stage IV there was no patient who survived up to 3 years. Patients with stage IV ovarian cancer (4 patients), survived for 7 days, 4 days, 3 days, and some even died before 24 hours postoperatively ( 0 days). From these results it can be concluded that the higher the stage, the lower the chance of survival. Log rank test results showed significant correlation $(\mathrm{p}<0.001)$ between stages with 3 years survival. Research in Iran also showed a similar thing with a value of $\mathrm{p}=0.0377 .{ }^{10}$ 
Table 2. Analysis of three-year patient survival bivariate epithelial ovarian cancer

\begin{tabular}{|c|c|c|c|c|c|}
\hline \multirow{2}{*}{ Variable } & \multirow{2}{*}{$\begin{array}{c}\text { Kaplan } \\
\text { Meier }\end{array}$} & \multirow{2}{*}{ Log rank } & \multicolumn{3}{|c|}{ Cox Regression } \\
\hline & & & $\mathrm{p}$ & HR & $95 \% \mathrm{CI}$ \\
\hline Whole & 0.585 & & & & \\
\hline Stage & & $\mathrm{p}<0.001$ & & & \\
\hline - Stage I & 0.893 & & 0.000 & 1 & \\
\hline - Stage II & 0.444 & & 0.004 & 6.782 & $1.816-25.327$ \\
\hline - Stage III & 0.351 & & 0.000 & 8.707 & $2.993-25.329$ \\
\hline - Stage IV & 0 & & 0.000 & 208.399 & $36.954-1175,251$ \\
\hline Age at diagnosis & & $\mathrm{p}=0.653$ & & & \\
\hline - $\leq 50$ years old & 0.613 & & & 1 & \\
\hline$->50$ years old & 0.539 & & 0.653 & 1.164 & $0.600-2.258$ \\
\hline Ascites before operation & & $\mathrm{p}=0.001$ & & & \\
\hline - No ascites & 0.777 & & & 1 & \\
\hline - Ascites & 0.413 & & 0.001 & 3.503 & $1.642-7.473$ \\
\hline The size of tumor before operation & & $\mathrm{p}=0.279$ & & & \\
\hline$-<10 \mathrm{~cm} 3$ & - & & - & - & \\
\hline$-10-50 \mathrm{~cm} 3$ & 1 & & 0.488 & 1 & \\
\hline$->50-200 \mathrm{~cm}^{3}$ & 0.808 & & 0.928 & 3306.529 & $0.000-7529.286$ \\
\hline$->200-500 \mathrm{~cm}^{3}$ & 0.490 & & 0.918 & 10845.253 & $0.000-2458.389$ \\
\hline$->500 \mathrm{~cm}^{3}$ & 0.565 & & 0.919 & 9331.904 & $0.000-2114,460$ \\
\hline Residual Tumor & & $\mathrm{p}=0.004$ & & & \\
\hline - No & 0.629 & & & 1 & \\
\hline$-\leq 1 \mathrm{~cm}$ & 0.146 & & 0.006 & 3.240 & $1.400-7.499$ \\
\hline$->1 \mathrm{~cm}$ & - & & & - & - \\
\hline Histopathology type & & $\mathrm{p}=0.041$ & & & \\
\hline - Mucinous & 0.804 & & 0.066 & 1 & \\
\hline - Serous & 0.427 & & 0.005 & 3.648 & $1.477-9.012$ \\
\hline - Endometrioid & 0.400 & & 0.086 & 3.370 & $0.842-13.493$ \\
\hline - Clear cell & 0.667 & & 0.452 & 1.704 & $0.425-6.823$ \\
\hline - Miscellaneous & 0.500 & & 0.117 & 0.726 & $0.726-17.857$ \\
\hline
\end{tabular}

Three-years survival rate in the age group $\mathbf{5 0}$ years was $61.3 \%$, and $>50$ years was $53.9 \%$. Log rank test results showed no significant correlation $(\mathrm{p}=0.653)$ between age and 3 years survival. These results are in contrast to the existing theory, but previous studies also showed no significant result such as in RSKD with $\mathrm{p}=0.134$, in Iran with a value of $p=0.613$, and in Greece with value of $\mathrm{p}=0.063^{6,10,11}$

Three-years survival in patients without ascites was $77.7 \%$, and with ascites was $41.3 \%$. Log rank test results showed significant correlation $(\mathrm{p}=0.001)$ between the presence of ascites with 3 years survival, where the presence of ascites would make survival lower. Other studies also suggested that there was a relationship between ascites with survival ( $\mathrm{p}<$ 0.001). ${ }^{12}$ Epithelial ovarian cancer patients with ascites had 3.503 greater risk of death compared to those without ascites. The presence of ascites will increase the risk of death.

The smallest size/ volume of tumors $\left(10-50 \mathrm{~cm}^{3}\right)$ had the highest 3 years-survival that was $100 \%$ (2 patients). While the largest size of tumor's(>500 cm3) 3year survival rate was not the lowest $(56.5 \%)$. 3-year survival is the lowest in tumor size $>200-500 \mathrm{~cm} 3$ that was $49 \%$ (25 patients). Log rank test results showed no significant relationship $(\mathrm{p}=0.279)$ between tumor size and 3 years survival. Not many research on tumor size were associated with survival. Research on Progression Free Survival defined the size of the tumor as the size of the largest mass with categories of $\leq 10 \mathrm{~cm}$ and $>10$ cmdiameter, and the log rank test results revealed no correlation. $^{13}$

Three-year survival rate in patients that were not contained residual tumor was $62.9 \%$, and in patients with residual tumor $(\Delta \mathrm{cm}$ ) was $14.6 \%$. Log rank test results showed significant correlation $(\mathrm{p}=0.004)$ between the residual tumor with 3 years survival, the greater the residual tumor, the smaller the chance of survival. The results of this study are similar to other studies that found a strong link between residual tumor with survival. ${ }^{14,15}$ Patients with residual tumor sized 0.1$1 \mathrm{~cm}$ were at risk of dying 2.31 times greater compared with patients who had microscopic residual tumor, and patients with residual tumors $>1 \mathrm{~cm}$ were at risk of dying 2.45 times greater than patients who had microscopic tumor residue. ${ }^{12}$ So the larger the residual tumor, the greater the risk of death. 
Table 3. Multivariate analysis of three-yearssurvival in epithelial ovarian cancer patients

\begin{tabular}{|c|c|c|c|c|c|}
\hline \multirow{2}{*}{ Variables } & \multirow{2}{*}{ B } & \multirow[b]{2}{*}{$\mathrm{p}$} & \multirow{2}{*}{$\begin{array}{c}\text { Hazard } \\
\text { Ratio }\end{array}$} & \multicolumn{2}{|c|}{$95 \% \mathrm{CI}$ for $\mathrm{HR}$} \\
\hline & & & & Lower & Upper \\
\hline Stages & & & & & \\
\hline $\begin{array}{ll}\text { - } & \text { Stage I } \\
\text { - } & \text { Stage II } \\
\text { - } & \text { Stage III } \\
\text { - } & \text { Stage IV }\end{array}$ & $\begin{array}{l}1.914 \\
2.164 \\
5.339\end{array}$ & $\begin{array}{l}0.000 \\
0.004 \\
0.000 \\
0.000\end{array}$ & $\begin{array}{c}6.782 \\
8.707 \\
208.399\end{array}$ & $\begin{array}{c}1.816 \\
2.993 \\
36.954\end{array}$ & $\begin{array}{c}25.327 \\
25.329 \\
1175.251\end{array}$ \\
\hline
\end{tabular}

3-year survival based on the type of histopathologywas ranging from the highest to the lowest; mucinous $(80.4 \%)$, clear cell $(66.7 \%)$, miscellaneous $(50 \%)$, serous $(42.7 \%)$, and endometrioid (40\%). These results are in contrast to the theory that histopathologic type of clear cell has the highest incidence of recurrent with the shortest survival so clear cell prognosis is generally poor. ${ }^{5,16}$ In this study, clear cell and serous had 3 years survival better than endometriod, but still lower than mucinous. The sequence is consistent with the theory that the mucinous type of histopathology has better prognosis than serous. ${ }^{17}$ The results of this study were similar to other studies which suggested that patients with mucinous and clear cell type of histopathology had better survival rate than the patients with serous type. ${ }^{18}$ The differences between the theoretical results with the results of this study could possibly happen due to lack homogenity of the sample. The sample in this study used all stages of epithelial ovarian cancer.Maybe the results will be more accurate in the same stage, for example, only using samples of stage III. Log rank test results showed no significant correlation $(\mathrm{p}=0.041)$ between the type of histopathology with 3 years survival.

Variables that could be included in the multivariate analysis were the stage, ascites, residual tumor and histopathologic types. In Cox regression test results, only the stage variabel gave highly significantvalue, with $\mathrm{p}<0.001$. This means that ascites, residual tumor, histopathological types variables influenced the survival rate individually, but not cumulatively. Thus, the prognostic factors that most influence the 3-years survival rate of epithelial ovarian cancer patients is the stadium.

Stage II epithelial ovarian cancer patients had mortality risk 6.782 (95\% CI 1.816 to 25.327$)$ greater than stage I. Patients with stage III epithelial ovarian cancer had the risk of death increased 8.707 times (95\% CI 2.993 to 25.329) greater than stage I. Patients with stage IV epithelial ovarian cancer had risk of death 208.399 times (95\% CI 36.954 to 1175.251 ) greater than stage I. From these results it can be concluded that the higher the stage, the risk of dying is higher.
The previous study also mentioned that the stage is a prognostic factor in survival after multivariate analysis. $^{6,11,19}$ The results in RSKD Jakarta said prognostic factors that most influence the survival of epithelial ovarian cancer were stage, ascites, hemoglobin and albumin. ${ }^{6}$ Prognostic factors that affecting survival the most based on the results of research in Greece was stage, residual tumor, performance status, and tumor cell types. ${ }^{11}$ Research in Germany said a prognostic factor that influenced survival the most was the stage, residual tumor, age, and peritoneal carcinomatosis. $^{19}$

\section{CONCLUSION}

Three-years survival rate of epithelial ovarian cancer patients overall was $58.5 \%$. Prognostic factors associated with3 years-survival of epithelial ovarian cancer patients were clinical stage, ascites, residual tumor and histopathologic types. Meanwhile age and the size of tumor was not associated with 3 years survival of epithelial ovarian cancer patients. Prognostic factors that most influence the 3 years survival of epithelial ovarian cancer patients was clinical stage, with a survival rate of $89.3 \%$ for stage I, $44.4 \%$ for stage II, $35.1 \%$ for stage III, and no patients survive up to 3 years in patients with epithelial ovarian cancer stage IV. Early detection of ovarian cancer is very necessary because ovarian cancer that is found and treated at an early stage had better prognosis andsurvival compared with ovarian cancer treated at an advanced stage.

\section{REFERENCES}

1. Rasjidi I. Epidemiologi Kanker pada Wanita. Jakarta: Sagung Seto; 2010. p. 289-349.

2. Epithelial Ovarian Cancer. Available from http:// www.who.int/entity/selection_medicines/committe es/expert/20/applications/EpithelialOvarian.pdf?ua $=1.2014$. Accessed 16 Jul 2016.

3. Estimated Cancer Incidence, Mortality and Prevalence Wordlwide in 2012. Available from http://globocan.iarc.fr/Default.aspx. 2012. Accessed 10 Jul 2016.

4. Busmar B. Kanker Ovarium. Dalam: Aziz MF, Andrijono, Saifuddin AB. Onkologi Ginekologi. Jakarta: Yayasan Bina Pustaka Sarwono Prawirohardjo; 2006. hal. 468-525.

5. Rasjidi I. Deteksi Dini dan Pencegahan Kanker pada Wanita. Jakarta: Sagung Seto; 2009. hal. 183201.

6. Nurrika D. Analisis Ketahanan Hidup Lima Tahun Pasien Kanker Ovarium Epithelial di Rumah Sakit 
Kanker Dharmais Jakarta. Tesis. Jakarta: Universitas Indonesia. 2010.

7. Ovarian Cancer Survival Statistic. Available from http://www.cancerresearchuk.org/health professional/ cancer-statistics/ statistics-by-cancer-type/ ovarian-cancer/survival\#heading-Zero. 2014. Accessed $10 \mathrm{Jul} 2016$.

8. Grann AF, Mette N, Jan B, Erik SA, Jacob BJ. Survival of patients with ovarian cancer in central and northern Denmark. Clinical Epidemiology. 2011;21(1-3):59-64.

9. Sriplung $\mathrm{H}$ and Prechavittayakul P. Cancer survival in Songkhla, Thailand, dalam Sankaranarayanan $\mathrm{R}$ and $\mathrm{R}$ Swaminathan. Cancer survival in Africa, Asia, the Caribbean and Central America. Lyon: International Agency for Research on Cancer. 2011:227-35.

10. Zarchi MK, Seyed MRM, Nasrollah B, Neda Z, Mahbube Z, Pouria YA, et al. The clinicopathologic characteristics and 5-year survival rate of epithelial ovarian cancer in Yazd, Iran. Electronic Physician. 2015;7(6):1399-406.

11. Bamias A, Sotiropoulou M, Zagouri F, Trachana P, Sakellariou K, Kostouros E, et al. Prognostic evaluation of tumour type and other histopathological characteristics in advanced epithelial ovarian cancer, treated with surgery and paclitaxel/ carboplatin chemotherapy: cell type is the most useful prognostic factor. European Journal of Cancer. 2011;48:1476-83.

12. Fader AN, Java J, Ueda S, Bristow RE, Armstrong DK, Bookman MA, et al. Survival in women with grade 1 serous ovarian carcinoma. Obstetrics \& Gynecology. 2013;122(2).
13. Peiretti M, Zanagnolo V, Aletti GD, Bocciolone L, Colombo N, Landoni F, et al. Role of maximal primary cytoreductive surgery in patients with advanced epithelial ovarian and tubal cancer: surgical and oncological outcomes. Gynecol Oncol. 2010;119(2):259-64.

14. Polterauer S, Vergote I, Concin N, Braicu I, Chekerov R, Mahner S, et al. Prognostic value of residual tumor size in patients with epithelial ovarian cancer FIGO stages IIA-IV. International Journal of Gynecological Cancer. 2012;22(3):3805.

15. Lutgendorf SK, Geest KD, Bender D, Ahmed A, Goodheart MJ, Dahmoush L, et al. Social influences on clinical outcomes of patients with ovarian cancer. Journal of Clinical Oncology. 2012;30: 2885-90.

16. Adrijono. Sinopsis Kanker Ginekologi. Jakarta: Balai Penerbit Fakultas Kedokteran Universitas Indonesia; 2013. hal. 87-287.

17. Jihong L. Tumor Ganas Ovarium, dalam Wan Desen. Buku Ajar Onkologi Klinis. Edisi ke-2. Jakarta: Balai Penerbit FKUI; 2011. hal. 517-26.

18. Chiang YC, Chen CA, Chiang CJ, Hsu TH, Lin MC, You SL, et al. Trends in incidence and survival outcome of epithelial ovarian cancer: 30-year national population-based registry in Taiwan. $\mathrm{J}$ Gynecol Oncol. 2013;24(4):342-51.

19. Trillsch F, Woelber L, Eulenburg C, Braicu I, Lambrechts S, Chekerov R, et al. Treatment reality in elderly patients with advanced ovarian cancer: a prospective analysis of the OVCAD consortium. Journal of Ovarian Research. 2013;6. 